\title{
Research on the Construction of Innovation and Entrepreneurship Teaching System Based on Computer Science and Technology
}

\author{
Yu Jiajie \\ (Qilu Normal University Jinan, Shandong Province 250000) \\ 1035806002@qq.com
}

\begin{abstract}
Keywords: Computer Science and Technology; Innovation and Entrepreneurship; System Research
\end{abstract}

\begin{abstract}
Computer science and technology is one of the most rapidly developing and changing majors in the 21 st century. It is continuously updated and continuously expanded in new fields of application. Colleges and universities are one of the important bases for training computer science and technology professionals. It is an important task for colleges and universities to deepen innovation and entrepreneurship education to meet the characteristics of computer science and technology in colleges and universities. Based on " Mass entrepreneurship and innovation " and "Internet Plus" in the form of new economy era background, based on the characteristics of university students, this article expounds the college of computer science and technology professional students should have computer ability and the service for the college students' innovative entrepreneurial activity of the construction of the curriculum system of the computer science and technology, and puts forward Suggestions on related the construction of teaching system.
\end{abstract}

\section{Introduction}

Riding on the wings of "Internet Plus", innovation, entrepreneurship and "Internet Plus" form a new wave and open up a new phase of "Internet Plus innovation and entrepreneurship". This wave engulfed colleges and universities and affected a wide range of young people, including undergraduate students and newly graduated professional people with a certain entrepreneurial foundation. Computer science and technology play a decisive role in cultivating students' awareness of innovation and entrepreneurship and in the development of innovative entrepreneurial potential. And computer technology and science are relatively more creative and entrepreneurial. In universities and colleges, innovation, entrepreneurship education, and the establishment of entrepreneurship bases have all been actively encouraged to encourage college students to start their own businesses. So how to train students in computer science and technology to innovate and start a business, how to provide services for college students and provide knowledge base are worth considering. This paper discusses how the basic curriculum construction of computer science and technology can train the innovation ability of college students and provide knowledge foundation for college students' entrepreneurship.

\section{Research Status of Computer Science and Technology Innovation and Entrepreneurial Talents}

\section{Insufficient Talent}

The current computer talent cultivation can not meet the needs of the market "Internet Plus" era of great demand for innovative talents of computer professionals, but few people meet the market demand. The reason is that the computer products and technology are rapidly updated. The curriculum system setting and teaching contents of the college computer specialty cannot be synchronized with it, which leads to non-use and non-learning. Therefore, it is particularly important to cultivate excellent "double-creation" computer talents.

\section{Separation of Creative Education from Computer Education}

The professional education of China's higher education is based on the professional talent 
training program. Its professional curriculum system is set in advance. At present, innovation and entrepreneurship education in most colleges and universities is only a matter of increasing the number of innovation and entrepreneurship courses. These courses are basically independent of professional learning. The innovation and entrepreneurship knowledge received by students cannot be integrated with computer professional knowledge. It is difficult to apply the theory of innovation and entrepreneurship in professional practice, and it is difficult for the innovation and entrepreneurship education in colleges and universities to effectively meet the needs of enterprises for computer professionals.

\section{Exploration on Training Talents for Innovation and Entrepreneurship in Computer Science and Technology}

Universities are the main channel for production, management, and service and the training of highly skilled personnel. Cultivating innovative and entrepreneurial talents is the subject of current university education research. Previous studies have been confined to the study of curriculum systems and curriculum content. They have not considered the impact of job requirements on job creation, and have not involved innovation and practice. There are no specific requirements for the construction of the teaching staff, either. Through two years of practice, based on the analysis of the needs of professional occupations in the industry, we have adjusted the training objectives and training system for computer science and technology professionals, and strengthened the training of practical skills, innovative thinking, and entrepreneurial qualities for computer science and technology professionals.

Focusing on the development of professional job skills, we will promote the cultivation of innovative, entrepreneurial and highly skilled personnel based on professional positions. Integrate talents and teaching resources in the industry and colleges and universities, strengthen professional and teacher team building, reform professional personnel training models, and use innovation and entrepreneurship teams as carriers to cultivate computer innovations and entrepreneurships that meet the needs of society through curriculum teaching reform and the construction of innovative training bases. Skilled personnel.

\section{Computer Science and Technology Course System Subject}

\section{Curriculum system concept}

The curriculum system is a system composed of various elements of the curriculum. It is formed under the guidance of a certain concept of educational values. It makes the curriculum elements in a dynamic change throughout the process, and points to the system to achieve the goals of the curriculum system. Under the background of innovation and entrepreneurship education, the standardized system of curriculum will have a profound effect on the preparation of entrepreneurial copywriting or creative copywriting for the majority of school students or graduated start-up groups, and help them improve the reporting materials needed for the roadshow.

\section{Curriculum System Construction Guidelines}

The selection of computer science and technology elective courses is mainly based on highly applicable courses. It adapts to the high-skilled, innovative, and entrepreneurial talent training objectives of "re-foundation, strong practice, brave innovation, and heavy application", highlighting the Importance of Science and Technology Elective Courses practical teaching in computers. Students can start from their own points of interest and adapt to their own professional or potential courses. In the course of setting elective courses in computer science and technology, colleges and universities need to take strict measures in the formulation of course systems, selection of courses, etc., and conduct surveys and studies on students and newly emerging professionals who have graduated within three years through questionnaires and interviews. Understand their interest in unknown knowledge by this way. The computer science and technology elective course system formulated in this way is in line with the learning needs of the students and meets the needs of the emerging entrepreneurs in innovation and entrepreneurship. It is worth learning from the 
universities.

\section{Curriculum System Direction}

The research of computer science and technology selection system aims to link innovation and entrepreneurship education with computer science and technology applications. Combining the construction of computer science and technology curriculum system with the needs of students in learning interest and the needs of emerging professionals, realizing computer science and technology system building and serving the ultimate goal of innovation and entrepreneurship education. Through questionnaires or interviews with students and new professional people, we investigate their interest and work needs outside of their professional or professional field. We sorted out the construction of computer science and technology elective course system should start from the following aspects.

Firstly, horizontally optimize course content. Conducting the retrieval and utilization of online information resources and literature lectures, popularizing the retrieval and use of online information resources and documents among all students.

Secondly, optimize the content of the course vertically. Conduct short-term training on advanced application courses such as the OFFICE series of software, PREZI, FOCUSKY, etc., and give targeted lectures on how to edit entrepreneurial copywriting, creative copywriting, and roadshow reporting.

Thirdly, the reform of the teaching staff construction. The introduction of lecturers with enterprise entrepreneurial experience, task-based short-term experiment training, and personalization of innovation and entrepreneurship guidance.

Fourthly, innovation in teaching model reform. The traditional teaching model centered on "teacher + multimedia + teaching materials" no longer adapts to the requirements of the cultivation of entrepreneurial talents in colleges and universities. We must further explore the reform of the teaching model and explore a new model that is conducive to teacher guidance and student self-learning and independent innovation. This will benefit both the construction of existing knowledge and the exploration of unknown knowledge.

\section{Computer Science and Technology Major Innovative Talents Cultivation Mode Reform}

"Awareness-spiritual-competence" is the core of innovation and entrepreneurship education. The first to cultivate innovation and entrepreneurship is to cultivate awareness of innovation and entrepreneurship. The focus of cultivating innovation and entrepreneurship awareness is to cultivate innovative entrepreneurial thinking, and classrooms are the main battlefield for the cultivation of new ideas. Therefore, the reform of innovation and entrepreneurship education should fully emphasize the reform of the curriculum system. The curriculum should actively learn from the trial experience of universities at home and abroad and the successful experience of innovation and entrepreneurship at home and abroad. Change in key areas such as course content, knowledge learning methods, assessment methods and evaluation standards, practice teaching methods and ability training methods.

\section{Curriculum system construction}

The curriculum consists of three levels: general education, professional basic courses and professional courses. General education courses are mainly composed of ideology, mathematics, foreign languages, sports, innovation and entrepreneurship theory and other courses; Professional basic courses are mainly composed of courses such as electrical, programming languages, software foundations, software development, and innovative technologies.

Professional courses are mainly used in database application, network, PC platform development, mobile platform development, embedded development, software engineering, software innovation basic courses, innovation and entrepreneurial quality development courses that reflect the latest trends in professional technology, training The project consists of engineering practice courses, innovative and entrepreneurial integrated practical courses and graduation design.

In the above course system, the cultivation of innovation and entrepreneurship awareness is mainly accomplished by the "Introduction to Computer Innovation and Entrepreneurship". 
Innovative and entrepreneurial thinking is mainly accomplished by courses such as "innovative thinking and innovative methods", "project management and corporate management", "risk management", and "innovation and entrepreneurship development curriculum group". The innovation ability training mainly consists of experimental practice courses such as "Innovation Quality Development Course", "Entrepreneurship Quality Development Course", "Innovation and Entrepreneurship Recognition Practice", "Innovation and Entrepreneurship Expansion Practice" and "Engineering Practice", and "Innovation and Entrepreneurship Comprehensive Practice". The entire university has cultivated students' innovative spirit and entrepreneurial awareness through various ways in four years.

\section{Practical teaching design}

The training of innovative engineering talents in the field of innovation and entrepreneurship in the field of software starts from the first grade and runs through the university for four years. In order to realize the goal of fostering innovation and entrepreneurship, we established a practical curriculum system and divided all practical courses into three levels: Basic theory and basic skills training, professional ability training, engineering practice and innovative practice. Gradual transition from low to high levels, basic theory and basic skills training and professional ability training are the main objectives of students' basic ability development; Professional ability training focuses on cultivating students' professional practice ability, innovation ability, and teamwork ability, enabling students to cultivate cooperative spirit, train communication and communication skills, and track the latest technology and entrepreneurial trend in the context of teamwork. The innovative training of engineering practice, innovation and practice takes the innovation and entrepreneurial ability and engineering application ability as training objectives, and comprehensively cultivates the students' professional quality, engineering ability, innovation and entrepreneurship, and innovation and entrepreneurship. Practice is to make students participate in the practice of innovation and entrepreneurship through practical innovation and entrepreneurship projects.

\section{Teaching content update}

The base has updated the teaching content of the pilot professional in the following aspects:

(1) Incorporate innovation and entrepreneurship education into the daily teaching system. To reduce the number of credit hours for regular courses, most courses will reduce credits, and innovation and entrepreneurship courses and innovation and entrepreneurship training will increase credits for practical courses.

(2) Enhance the awareness of innovation and entrepreneurship of all teachers in the base. All courses (except for individual lessons) for pilot professional courses are required to add certain innovation and entrepreneurship training content in curriculum teaching. By introducing the latest developments in the field, latest technologies, and innovation and entrepreneurship cases, innovation and entrepreneurship education content will be integrated into each course.

(3) The contents of reform practice courses emphasize the combination of theory and practice, emphasizing practice teaching. The practical content of practical lessons, especially professional courses and professional basic courses, should be close to the actual situation and reflect the latest technological trends and entrepreneurial trends. Every academic year should be preceded by a practice class for new students to report on the latest technical practical lesson plans and programs.

(4) Increase the concentration of practice. Focusing on practice is an indispensable and practical teaching link that enables students to acquire direct knowledge and consolidate the theory they have learned. It is an important guarantee for achieving professional training goals. Increase the credits for engineering practice and social practice in the training plan, and truly regard practice as an effective way to improve the overall quality of students and cultivate their practical ability and innovative spirit.

(5) Increase credit for innovation and entrepreneurship practice. In the practice of innovation and entrepreneurship, students are allowed to select topics, organize teams, collect information, conduct research or entrepreneurial activities under the guidance of teachers, highlighting the 
nature of education innovation.

(6) Integrate research and teaching. Advocating the combination of teaching and research projects, requiring teachers not only focus on imparting knowledge in class, but should consider the major theoretical issues and cutting-edge issues involved in the curriculum. Encourage scientific research projects and innovative project case-driven teaching.

\section{Summary}

The training of innovative and entrepreneurial talents in computer science and technology requires the vigorous cooperation of the government and universities. It requires constant construction of teachers and continuous reform of teaching models. Although many colleges and universities have made rapid progress, it is still a long way to go to integrate innovation and entrepreneurship education into teaching practice. All parties need to make unremitting efforts.

\section{References}

[1] Sun H. The 3-3-3 framework and 7P model for teaching creativity, innovation and entrepreneurship[J]. IEEE Engineering Management Review, 2012, 40(2):157-163.

[2] Laperche B. Entrepreneurial Behavior and Eco-Innovation[J]. Encyclopedia of Creativity Invention Innovation \& Entrepreneurship, 2013:598-603.

[3] Carayannis E G, Campbell D F. Editorial preface to the first volume of Journal of Innovation and Entrepreneurship[J]. Journal of Innovation \& Entrepreneurship, 2012, 1(1):1.

[4] Balasubramanyam S. CREATIVITY AND INNOVATION: IMPORTANT DRIVERS OF ENTREPRENEURSHIP[J]. International Journal of Research in Computer Application \& Mana, 2014.

[5] Orchard S. Entrepreneurship and the Human Capital of Organizational Innovation: The Intrapreneur[J]. 2015.

[6] Ramanantsoa B. Entrepreneurship and Innovation: Business Schools as Drivers of Change[M]// Shaping Entrepreneurial Mindsets. Palgrave Macmillan UK, 2015.

[7] Zhu R, Peng P. Construction of Mobile Service Platform for Innovation and Entrepreneurship in Universities[J]. Modern Computer, 2016.

[8] Newell B S, Varshney L R. The first cohort in a new innovation, leadership, and engineering entrepreneurship B. S. degree program[C]// IEEE Frontiers in Education Conference. IEEE Computer Society, 2017:1-6.

[9] Liang K, Shun-Ren H U, Shuang L I, et al. Exploration on Innovation and Entrepreneurship Education of Students in Applied Universities[J]. Computer Knowledge \& Technology, 2017.

[10] Cunningham P. Insights into open innovation and ICT entrepreneurship in Africa[C]// IEEE International Symposium on Technology and Society. IEEE, 2016:1-8.

[11] Yong L I, Lei Y, Gao H T, et al. Research on the Role of Internet in Innovation and Entrepreneurship Education[J]. Modern Computer, 2017.

[12] Feng Y R, Fan F, Jing J L. Innovation and Entrepreneurship Training as the Core of the Computer Class Public Elective Course Teaching Reform[J]. Education Teaching Forum, 2017.

[13] Wang Y. Development and Implementation of Innovation and Entrepreneurship Project Management System for College Students[C]// International Conference on Intelligent Transportation, Big Data \& Smart City. IEEE Computer Society, 2018:504-507.

[14] Zheng Q H, Wei L I, Zhou J H. Research on the Reform of Computer Specialty Curriculum Targeted on the Cultivation of Innovation and Entrepreneurship[J]. 2018. 